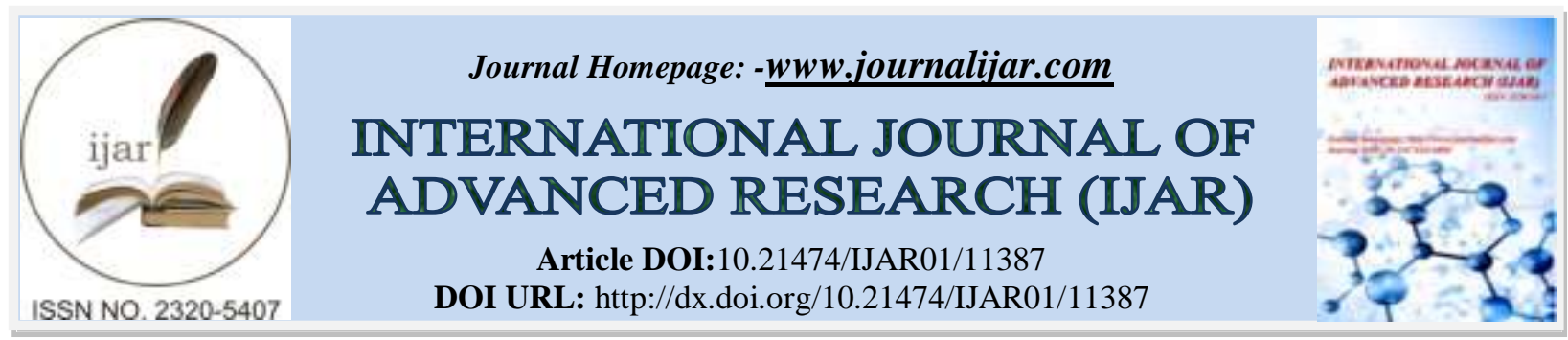

RESEARCH ARTICLE

\title{
PEDAGOGICAL COMPETENCIES OF PPKN VOCATIONAL SCHOOL TEACHERS CERTIFIED IN MANAGEMENT OF SEMESTER LEARNING (CASE STUDY OF STATE VOCATIONAL SCHOOL TEACHERS IN TERNATE CITY)
}

\author{
Irwan Djumat, Hasmawati and Nani I. Rajaloa
}

Khairun University, North Maluku, Indonesia.

\section{Manuscript Info}

.a.......................

Manuscript History

Received: 25 May 2020

Final Accepted: 28 June 2020

Published: July 2020

Key words:-

Pedagogical Competence, Certification, and Learning Management

\section{Abstract}

This research uses a descriptive qualitative approach with a case study research method. Data collection techniques used were, interview, participant observation (participant observation), and study documentation. The results showed that there were two pedagogical competencies for certified PPKn Vocational School teachers in Ternate City, first, medium level pedagogical competencies. After being certified there is no improvement in terms of learning management. Things like making syllabus, learning program plans, mastering teaching materials, class mastery, learning methods and models do not change only are conventional which is the routine task of the teacher both before and after being certified. While advanced level pedagogical competencies have not yet been found. This level of competence is seen from the mastery of the field of measurable teaching, the commitment to develop methods, models and tools of continuous learning, feasibility research for the continuous development of teaching materials, and participation in various activities, training, seminars, workshops, and good training limited scale at school, district and provincial, and national level.

Copy Right, IJAR, 2020,. All rights reserved.

\section{Introduction:-}

In the world of education, professional teachers are the main factor for improving the quality of human resources of students / students (Gumarova, et. al, 2016). The role of the teacher as an educator and instructor is that he must master knowledge, among others must have extensive knowledge, master the subject matter and the sciences related to the subject or field of study being taught, master the theory and practice of educating, curriculum theory and subject matter, educational technology, evaluation theory and learning psychology(Kuyini et. al, 2016; He et al, 2017) The various roles mentioned are included in the pedagogical competence that must be possessed by a teacher.

Pedagogical competence is an ability with regard to students' understanding and management of learning that is educative and dialogic (Mirzagitova and Akhmetov, 2015; Lauermann and Koig, 2016). Pedagogical competence is a number of teacher abilities related to the science and art of teaching students (Abosi and Alhassan, 2017). In Law No. 14 of 2005 concerning Teachers and Lecturers explained that pedagogical competence is the ability to manage learners' learning (Law No. 14, 2005) Explained by Andryukhina, et al (2016) that pedagogical competence is an understanding of students to actualize the various potentials that students have 
Thus it can be said that teachers who have pedagogical competence are teachers who can understand students, teachers who understand learning theories both theory and practice, compile learning devices using the media or not, are able to evaluate learning activities, and can also provide motivation to develop abilities students (Raju, 2017; Katarzyna, et. al, 2018)

In Law No. 14 of 2005 article 1 explained that the teacher is a professional educator with the main task of educating, teaching, guiding, directing, training, evaluating, and evaluating students in early childhood education through formal education, basic education and secondary education(Riyad, et. al, 2020). Recognition of the position of the teacher as a professional as referred to in paragraph (1) is evidenced by an educator certificate (Law No.14 / 2005: article 2). UU no. 14/2005 article 8 states that teachers must have academic qualifications, competencies, educator certificates, physically and mentally healthy, and have the ability to realize national education goals(Astuty, 2015). While the academic qualifications referred to in article 8 are obtained through higher education undergraduate programs or diploma four programs (Law No. 14/2005: article 9), and teacher competencies referred to in article 8 include pedagogical competencies, personality competencies, social competencies, and competencies professionals obtained through professional education (Law No.14 / 2005 article 10). This condition shows that a competent teacher is not born instantly but through a process of education, training, social selection process in carrying out their duties, teaching and learning process in schools, and selection and strengthening through certification. This means that to be competent must have a number of criteria set out in Law No. 14/2005 concerning teachers and lecturers(Law No. 14, 2005)Based on the above problems, the research on "Pedagogical Competence of PPKn Certified Vocational School Teachers in the Management of Semesteran Learning (Case Study on State Vocational School Teachers in Ternate City) is considered very urgent to be researched, on (1) how the pedagogical competence of PPKn Vocational School Certified Teachers in managing semester learning at State Vocational Schools in Ternate City; (2) obstacles encountered; and (3) how to overcome these obstacles.

\section{Teacher Pedagogical Competencies:}

In Law No. 14 of 2005 concerning Teachers and Lecturers, stated that pedagogical competence is "the ability to manage student learning". Ministry of National Education (Ministry of Education, 2014) calls pedagogical competence "learning management competency". According to Siswoyo (et. al, 2016), pedagogical competence is not merely technical competency, namely "competency in managing students" as formulated in Government Regulation No. 19 of 2005, because "pedagogy" or "pedagogy" is "the art and science of teaching and educating" (the art and knowledge of teaching and educating).

Substantively according to Damsar (2012) that pedagogical competence implies: the ability of teachers' understanding of students, the design and implementation of learning, evaluation of learning outcomes, and the development of students to actualize their various potentials. In detail, each element of this pedagogical competency can be described as follows: (a) understanding students. This competency includes essential indicators in understanding students by utilizing the principles of cognitive development, personality, and identifying students' early learning provisions; and (b) design learning. This competency includes essential indicators in terms of the application of learning and learning theory, establishing learning strategies based on the characteristics of students, the competencies to be achieved, teaching materials, and preparing learning designs based on the chosen strategy. In the national education standard in article 28 paragraph 3 point a, it is stated that the pedagogical competence of teachers is the ability to manage learners' learning[(Nintiyas and Jailani, 20180, design and implementation of learning, evaluation of learning outcomes and development of students to actualize the various potentials they have (Mulyasa, 2013).

Various explanations above concluded that pedagogical competence has an essential indicator in the form of facilitating students to develop various academic potentials; and facilitating students to develop various nonacademic potentials in various planned learning activities.

\section{Research Methods:-}

The method used in this research is the case study method. according to Creswell (1998), case study research is a study that explores a problem with detailed constraints, has in-depth data retrieval, and includes various sources of information. This research is limited by time and place, and cases learned in the form of programs, events. Activity, or individual. The qualitative approach with the case study method in this study is expected to be able to uncover aspects that were studied regarding the pedagogical competence of certified PPKn Vocational School teachers in the management of semester learning at State Vocational Schools in Ternate City. 


\section{Description of Research Results:-}

Pedagogical Competencies of PPKn Vocational School Teachers Certified in the Management of Semesteran Learning in State Vocational Schools in Ternate City.

Before describing the research findings, it is first explained about the distribution of PPKn Vocational School teachers, education, education studies, and certification study fields. This can be seen in the following table:

Table 1:- Teacher Name, School Name, Education, Field of Education Studies, and certification.

\begin{tabular}{|l|l|l|l|l|l|}
\hline No & Nama & School Name & Education & $\begin{array}{l}\text { Field of Education } \\
\text { Studies }\end{array}$ & Certification \\
\hline 1 & Ibrahim Samad & SMK Neg. 1 & $\begin{array}{l}\text { Bachelor } \\
\text { Degree (S1) }\end{array}$ & Civic Education & Certified \\
\hline 2 & Usman Rufai & SMK Neg. 1 & $\begin{array}{l}\text { Bachelor } \\
\text { Degree (S1) }\end{array}$ & Civic Education & Certified \\
\hline 3 & Ibrahim Hi. Usman & SMK Neg. 2 & $\begin{array}{l}\text { Bachelor } \\
\text { Degree (S1) }\end{array}$ & Civic Education & Certified \\
\hline 4 & Ida Lesang & SMK Neg. 2 & $\begin{array}{l}\text { Bachelor } \\
\text { Degree (S1) }\end{array}$ & Civic Education & Certified \\
\hline 5 & Mariyani Abuganda & SMK Neg. 2 & $\begin{array}{l}\text { Bachelor } \\
\text { Degree (S1) }\end{array}$ & Civic Education & Certified \\
\hline 6 & Nurhayati Basimin & SMK Neg. 2 & $\begin{array}{l}\text { Bachelor } \\
\text { Degree (S1) }\end{array}$ & Civic Education & Certified \\
\hline 7 & Firdaus Salim & SMK Neg. 3 & $\begin{array}{l}\text { Bachelor } \\
\text { Degree (S1) }\end{array}$ & Civic Education & Certified \\
\hline 8 & $\begin{array}{l}\text { Muhammad } \\
\text { Muhammad }\end{array}$ & SMK Neg. 3 & $\begin{array}{l}\text { Bachelor } \\
\text { Degree (S1) }\end{array}$ & Civic Education & Certified \\
\hline 9 & Hasan Hamisi & SMK Neg. 4 & $\begin{array}{l}\text { Bachelor } \\
\text { Degree (S1) }\end{array}$ & Civic Education & Certified \\
\hline 10 & Rosiana Lahiri & SMK Neg. 5 & $\begin{array}{l}\text { Bachelor } \\
\text { Degree (S1) }\end{array}$ & Civic Education & Certified \\
\hline 11 & Irwan Saleh & SMK Neg. 5 & $\begin{array}{l}\text { Bachelor } \\
\text { Degree (S1) }\end{array}$ & Civic Education & Certified \\
\hline
\end{tabular}

Source: North Maluccas Province, Department of Education and Teaching, 2019

In table 1, it shows that the average PPKn Vocational High School teacher education in Ternate is a bachelor degree (S1), and has been certified, however the pedagogical competence still needs to be developed and improved.

Table 2:- Teacher Name, Education Level, Employment Status and Field of Certification Study.

\begin{tabular}{|l|l|l|l|lr|l|}
\hline No & Name & Education Degree & $\begin{array}{l}\text { Type of } \\
\text { PTK }\end{array}$ & $\begin{array}{l}\text { Employment } \\
\text { Status }\end{array}$ & $\begin{array}{l}\text { field of certification } \\
\text { study }\end{array}$ \\
\hline 1 & Ibrahim Samad & $\begin{array}{l}\text { Bachelor } \\
\text { Education (S1) of }\end{array}$ & $\begin{array}{l}\text { Subject } \\
\text { Teachers }\end{array}$ & $\begin{array}{l}\text { State of } \\
\text { apparatus }\end{array}$ & civil & civic education \\
\hline 2 & Usman Rufai & $\begin{array}{l}\text { Master } \\
\text { Education (S2) }\end{array}$ & $\begin{array}{l}\text { Subject } \\
\text { Teachers }\end{array}$ & $\begin{array}{l}\text { state } \\
\text { apparatus }\end{array}$ & civil & civic education \\
\hline 3 & Ibrahim Hi. Usman & $\begin{array}{l}\text { Bachelor of } \\
\text { Education (S1) }\end{array}$ & $\begin{array}{l}\text { Subject } \\
\text { Teachers }\end{array}$ & $\begin{array}{l}\text { state } \\
\text { apparatus }\end{array}$ & civil & $\begin{array}{l}\text { Physical education } \\
\text { and Health Sciences }\end{array}$ \\
\hline 4 & Ida Lesang & $\begin{array}{l}\text { Bachelor of } \\
\text { Education (S1) }\end{array}$ & $\begin{array}{l}\text { Subject } \\
\text { Teachers }\end{array}$ & $\begin{array}{l}\text { state } \\
\text { apparatus }\end{array}$ & civil & civic education \\
\hline 5 & Mariyani Abuganda & $\begin{array}{l}\text { Bachelor of } \\
\text { Education (S1) }\end{array}$ & $\begin{array}{l}\text { Subject } \\
\text { Teachers }\end{array}$ & $\begin{array}{l}\text { state } \\
\text { apparatus }\end{array}$ & civil & civic education \\
\hline 6 & Nurhayati Basimin & $\begin{array}{l}\text { Bachelor of } \\
\text { Education (S1) }\end{array}$ & $\begin{array}{l}\text { Subject } \\
\text { Teachers }\end{array}$ & $\begin{array}{l}\text { state } \\
\text { apparatus }\end{array}$ & civil & civic education \\
\hline
\end{tabular}




\begin{tabular}{|c|c|c|c|c|c|}
\hline 7 & Firdaus Salim & $\begin{array}{ll}\text { Bachelor } & \text { of } \\
\text { Education (S1) } & \\
\end{array}$ & $\begin{array}{l}\text { Subject } \\
\text { Teachers }\end{array}$ & $\begin{array}{ll}\text { state } & \text { civil } \\
\text { apparatus } & \\
\end{array}$ & civic education \\
\hline 8 & $\begin{array}{l}\text { Muhammad } \quad \text { Djisman } \\
\text { Ohoiyuff }\end{array}$ & $\begin{array}{ll}\text { Bachelor } & \text { of } \\
\text { Education (S1) } & \\
\end{array}$ & $\begin{array}{l}\text { Subject } \\
\text { Teachers }\end{array}$ & $\begin{array}{ll}\text { state } & \text { civil } \\
\text { apparatus } & \\
\end{array}$ & civic education \\
\hline 9 & Hasan Hamisi & $\begin{array}{ll}\text { Bachelor } & \text { of } \\
\text { Education }(\mathrm{S} 1) & \\
\end{array}$ & $\begin{array}{l}\text { Subject } \\
\text { Teachers }\end{array}$ & $\begin{array}{ll}\text { state } & \text { civil } \\
\text { apparatus } & \\
\end{array}$ & civic education \\
\hline 10 & Rosiana Lahiri & $\begin{array}{ll}\text { Bachelor of } & \text { of } \\
\text { Education (S1) }\end{array}$ & $\begin{array}{l}\text { Subject } \\
\text { Teachers }\end{array}$ & $\begin{array}{l}\text { state } \\
\text { apparatus }\end{array}$ & criminal justice \\
\hline 11 & Irwan Saleh & $\begin{array}{ll}\text { Bachelor of } \\
\text { Education (S1) }\end{array}$ & $\begin{array}{l}\text { Subject } \\
\text { Teachers }\end{array}$ & $\begin{array}{ll}\text { state } & \text { civil } \\
\text { apparatus } & \\
\end{array}$ & civic education \\
\hline
\end{tabular}

Source: North Maluccas Province, Department of Education and Teaching, 2019

Table 2, shows that of 11 certified PPKn Vocational School teachers, 9 (nine) were certified in accordance with the field of education while in strata 1 (S1), while one teacher was certified in physical and health education, and the other was certified in criminal justice. This shows that the level of education undertaken during the first stratum is not used as a basis for a teacher's competency certification in the field, so it can be said that the teacher's pedagogical competence is still far from the standards required in the teacher and lecturer law. The certification sector is not in accordance with the standardization of educational qualifications, so to measure the quality of learning outcomes in schools is not optimal or far from what is desired. Teacher qualifications and quality largely determine the quality of education produced. This condition needs to be a serious concern for policy makers in the field of education, if they want quality secondary education, because their students are prepared to go to higher education with more complex challenges, not just learning, but preparing themselves for the future and ready to compete in digital era.

Research findings in the field about Pedagogical Competence of PPKn Vocational School Teachers Certified in the Management of Semester Learning in State Vocational Schools in Ternate City, both from the main informants and the base informants in general can be explained as follows:

For aspects of certification, it can improve pedagogical competence. Both the main informant and the base informant found that after being certified the teacher felt burdened with responsibility as a professional teacher so that he was often motivated to improve his pedagogical abilities, especially the PPKn teacher even though he felt it had not been $100 \%$. This is as stated by Irwan Saleh PPKn State Vocational School Teacher 5 that "pedagogical competence is the science of educating where teachers especially PPKn teachers must understand the development of students, student characteristics, the right method for teaching subjects in class according to the material, then evaluating. We all teachers are required to have this ability. But in reality we teachers are only pedagogical abilities (moderate), there is no coaching between us, for example those who are more proficient to those who are not too proficient, including in terms of making learning tools ". In line with Irwan Saleh, Usman Rufai, a PPKn SMK Negeri 1 teacher who saw that pedagogical competence is scientific competency, namely teachers, especially we, PPKn teachers, must be able to carry out classroom learning well that is directly related to learning outcomes at school. However, the teacher is sometimes burdened by only carrying out his obligations to teach in the classroom, while his self-development is mediocre, not trying to be truly adept at developing his pedagogical competencies, so that he can foster others to become like him. "

For aspects of making learning models both basic informants and basic informants and the results of observations in the field indicate that PPKn teachers before carrying out the semester learning process it is mandatory to make instructional devices for guidance in teaching. This is as stated by Hasan Hamisi PPKn Vocational School teacher 4 and Djisman Ohoiyuf PPKn Vocational School 3 teacher that teachers especially PPKn teachers must make syllabus and RPP because we teach must be in accordance with the syllabus and RPP, where the syllabus and RPP are the reference is a teacher's guide when teaching in class ". Ibrahim Samad, a PPKn teacher at State Vocational School 1, said that the syllabus and lesson plans must be made independently by teachers, especially PPKn teachers, in order to be able to understand the learning tools first which are the teacher's guidelines before conducting teaching and learning in class. Asnidar Rusli State Vocational School 4 students view the syllabus and lesson plans as an integral part of the teacher's task in teaching in class so that when teaching teachers do not deviate from the material that has been made in the syllabus and lesson plans. In line with Asnidar Rusli, While students such as Poetry Aulia Umagap students of State Vocational School 5 and Waode students of State Vocational School 3 that teachers made syllabus 
and RPP then told us students at the beginning of face-to-face so that we could prepare ourselves by reading and looking for material to face teaching and learning process in class.

For the aspect of mastery of subject matter both the main informant and the base informant have the same view that the PPKn teacher on average masters the material being taught because of the experience and duration of being a teacher, and becomes his daily routine.

For aspects of classroom management both the main informant and the base informant, as well as the results of observations in the field show that all PPKn teachers have pedagogical abilities in terms of classroom management. However, there are schools where students learn during the teaching and learning process, the teacher must work extra to manage the class. This is as stated by Nurhayati Basimin, PPKn Vocational School Teacher 2 that "the way to manage classes is to arrange and manage students' seats varying so as not to be noisy when the teaching and learning process takes place remembering each student has a different character let alone dominated by male students. like us in SMK 2. If the class is not managed and there is a commotion, lessons are wasted (missed) ". Class management in addition to giving comfort to students, also avoiding noise, poking each other and throwing rolls of paper if there is a serious study (disrupting others who are concentrating. According to Djisman Ohoiyuf, PPKn Vocational School teacher 3, that "the way of classroom management is to set the place sitting students, using standard language, the voice must be loud.Thus the teaching and learning process will run smoothly and the atmosphere becomes comfortable. This seating arrangement if not applied, then when the learning process occurs there is often a stir (poking each other, throwing rolls of paper into direction of friends who are serious when learning) if we are teachers in delivering material in front of the class just look away from the students for as long as possible. The teacher should be creative to organize the class for the purpose of learning ".

For aspects of the use of methods, media and learning sources, both basic informants and base informants, it was found that the most dominant method used by teachers was lectures, questions and answers and group discussions, this is the conventional method that has been used by PPKn teachers. The inquiry method is casuistic only to certain teachers who frequently participate in training such as Usman Rufai State Vocational School Teacher 1. While for media and learning resources, PPKn teachers use laptop, infocus and hand phone with Wifi facilities at school. According to M. Fajri Sidi Umar, a student of SMK Neg 2, the teacher uses the lecture method, questions and answers and group discussions, while learning media sometimes uses teachers depending on the material being taught. In line with Fajri, Melani, a student at State Vocational School 1, also said that PPKn teachers teach using lecture, question and answer and discussion methods, while the learning media used are laptop, infocus and hand phone.

For the evaluation aspects of learning, both basic information and basic informants, it is found that PPKn teachers always provide both written and oral evaluations to measure the level of achievement of the material being taught. This is as stated by Djisman Ohaiyuf, a Vocational School 3 teacher, that the evaluation forms provided were posttest, quiz, and midterm exam (UTS-Indonesia). According to Mariyani Abaganda, teacher of PPKn SMK Negeri 2 that evaluation is important because it is to measure the ability of students from the material we provide, it also measures the level of our success in teaching, its evaluation form, written, oral and quiz form. According to Asnidar Rusli, a State Vocational School 4 student, the evaluation form given by the PPKn teacher was a written test and an oral test. Melani female students of SMK Negeri 1; Waode Students of State Vocational School 3; Poetry Aulia Umagap, a student of SMK 5; M. Fajri Sidi Umar, a student of SMK Negeri 2; and said that the PPKn teacher gave evaluations in the form of written tests and oral tests in the form of quizzes.

\section{Constraints faced by Certified Vocational School Teachers in Managing Semester Learning:}

Data collected in the field shows that the constraints faced by PPKn teachers in managing learning in each school are different. For new schools such as SMK Negeri 5, the obstacle faced is the lack of facilities and infrastructure. Neg 3 Vocational School is faced with incomplete student books so the teacher must look for other supports. Another case with State Vocational High School 1, for example, according to school principal Iswanto Marzuki, said that the obstacle faced was the absence of independent activities organized by the school due to collision with the unavailability of budget for quality improvement programs and the low operational costs of schools. While in the aspect of teaching and learning in the classroom, PPKn teachers such as Ibrahim Samat experience obstacles such as indifferent students, switching concentrations, imagining and telling stories. The solution is to restore their concentration by asking to repeat the core material that has been explained. While Usman Rufai PPKn Vocational School Teacher 1 and Djisman Ohaiyuf PPKn Vocational School Teacher 3 said that the constraints he often faces 
in class learning are limited class hours so that the material has not finished time has expired, the solution is at the next meeting the new material is completed (mastery learning). In State Vocational School 2. According to Usman Wahab wakasek curriculum that the obstacles faced by teachers in general in the process of teaching and learning are teachers faced with the characteristics of stubborn students, sometimes difficult to regulate because the majority of men, are bored with materials that only rely on memorization. According to Nurhayati Basimin, her PPKn teacher stated that "the obstacles faced are undisciplined, stubborn students, for example the indifferent attitude during the learning process, because the PPKn lessons are less attractive (memorize a lot) and cannot complete the homework given by the teacher. Not to mention the students are dominated by men. This is a challenge for us teachers in daily life at school how to change the nature of students who are likely with their parents at home too, "

\section{c.Solution to Overcome the Constraints encountered:}

Each school has the same complaint about coaching that does not work after the PPKn Vocational School teachers are certified. As if to show that the certificate of certification is to make teachers already have more provision in carrying out the task, without thinking about the quality and pedagogical skills of vocational teachers who teach students to be prepared for higher education levels. However, at each school also has a different way to improve the teacher's pedagogical abilities. In the sense of the policy of the leadership to use all the capabilities they have including the budget, as long as it does not violate the SOPs that have been set.

\section{Result and Discussion:-}

Pedagogical Competencies of Certified Vocational Teachers:

The pedagogical competence of certified PPKn State Vocational Schools teachers in Ternate City in the study, there were found two levels of competency categories. This can be described and explained as follows:

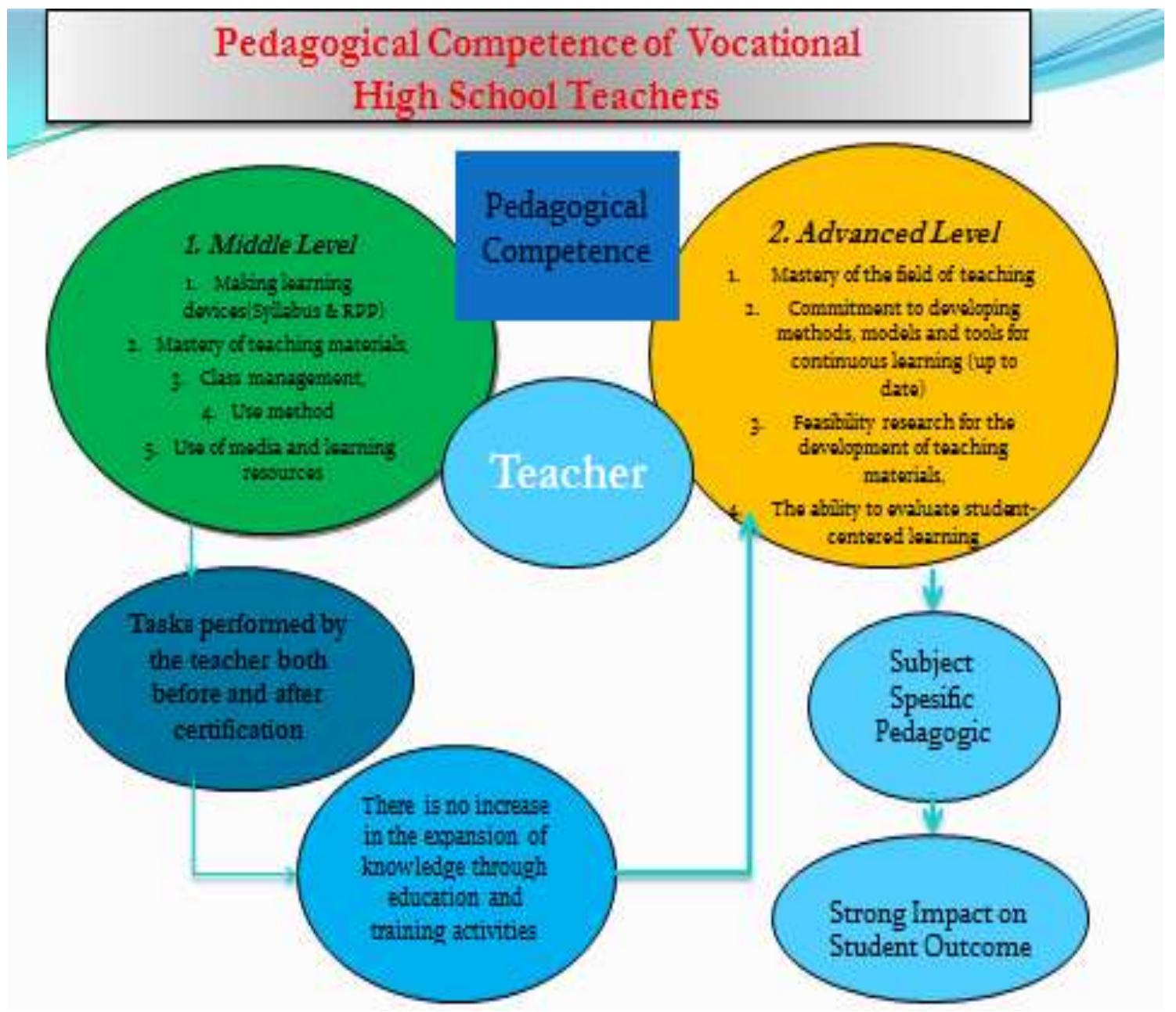

Figure 1:- Developed from research results, 2019. 


\section{Pedagogical Competencies of Middle Level Certified PPKn Teachers:}

Findings in the field obtained regarding the pedagogical competence of PPKn teachers certified in the management of learning indicate that all PPKn teachers have pedagogical competencies such as making learning devices (syllabus and lesson plans), mastery of teaching materials, classroom management, use of methods, media and learning resources, but do not experience learning. increased knowledge expansion to advanced level (having special skills in the field of pedagogical competence). For example, because of its ability to foster others in terms of pedagogical competence. The pedagogical competence they have so far is a routine activity that they have been doing for years, for updates and updates are not visible (not found). According Sukmadinata (2009), the pedagogical ability of teachers in managing learning, namely: (a) mastery of learning materials along with basic scientific concepts; (b) management of teaching and learning programs; (c) classroom management; (d) the use of media and learning resources; (e) mastery of educational foundations; (f) management of teaching and learning interactions; and $(\mathrm{g})$ assessment of student achievement in the teaching and learning process.

Coe et. al (2013) in their article entitled "What Makes Great Teachings? Review of the Underpinning Reasearch" revealed that there were six components that could make the learning process a very successful process. In Coe's terms, the learning process is called great teaching because it produces extraordinary learning outcomes seen from various basic competency measures and competency indicators. The six competencies are pedagogical content of learning, quality of instruction, classroom climate, classroom management, teacher beliefs, and professional behavior.

Pedagogical content of learning is the first component that contributes very strongly to the achievement of students' competencies. It becomes a very specific pedagogic application (subject specific pedagogic) according to the needs of the subject matter. Thus said Coe, pedagogic is a major component that is very influential on improving the quality of learning and providing strong impact on student outcomes, so that it becomes a great process, both in encouraging student participation and in their final ideal competence (graduation). Explained by Coe, the most effective teachers who can give birth to a great learning process are those who are very knowledgeable in teaching materials, are able to develop the learning process according to the material being taught, can understand how students think about the teaching materials they receive, can conduct evaluations, and even able to identify various misconceptions of students about the material they have just learned. Competence must be continuously honed and developed by a teacher as the development of learning technology.in carrying out their duties, teachers apply skills that meet certain quality standards or norms obtained through professional education (Vulliamy and Web, 2018), including certification and the level of guidance after certification. This will have an impact on improving the quality of schools.

\section{Pedagogical Competencies of PPKn Certified Teachers at Advanced Level:}

The findings in the field show that in fact the teacher's pedagogical ability is just like that (moderate), there is no ongoing coaching, for example those who are more proficient to those who are not too proficient, including in making learning tools. The teacher is sometimes burdened by only carrying out his obligations to teach in the classroom, while his self-development is mediocre, not trying to be truly adept at developing his pedagogical competencies, so that he can foster others to become like him. Proficient teachers who by Coe et al (2013) and Ferdinal call them great teachers need to keep learning, updating the latest information about teacher assignments. Add knowledge through mass media, print and electronic media, and have extensive networking. Thus the teacher will not miss the information needed in the teaching and learning process.

This advanced level of pedagogic competence can be tasked with guiding the moderate level to improve pedagogical competence. This advanced level of pedagogical competence is seen from:

1. Mastery of the field of teaching that is measured based on the results of the tiered evaluation and supervision at the school level;

2. Commitment to developing methods, models and tools for continuous learning;

3. Feasibility research for the development of teaching materials that have been taught continuously;

4. The ability to evaluate learning well that is centered on students authentically. Explained by Andersson and

Palm (2017) and Black and William (2018)that a good grading system must be able to help students achieve their learning goals. Although the teaching and learning process cannot be fully student-centered as in open education, what needs to be paid attention to is that basically, students must learn and develop themselves so that the assessment system applied must be based on student circumstances. Thus the teaching and learning process needs to 
be oriented to the needs and abilities of students. Activities carried out in teaching in the learning process must be able to provide a variety of learning atmosphere that is adequate for the material presented and adapt to the abilities and characteristics of students as subjects. Likewise, the assessment system must be in accordance with the principles of authentic assessment, which in many findings can lead to a significant increase in learning outcomes. In the research of Christie et al (2019), that assessment of learning activities is on an outcome-based approach.

This assessment system has valid, reliable and practical criteria. Valid is defined as accuracy in measuring students' abilities. Realiabilitu is interpreted as the level of consistency of the instrument while practically interpreted as ease of use. If it fulfills all aspects and principles of the assessment, it can be said as an authentic assessment. Authentic assessment has been previously considered in many aspects of educational evaluation (Vu and Dell'Alba, 2014: Forsyth and Evans, 2019). In realizing the result of the assessment in accordance with field conditions (in school), is necessary to continue develop a comprehensive assessment system with instruments that are more practical, valid, reliable, and sensitive to have good quality (Aman, 2019). In this case the quality of desired learning outcomes is in line with the school's goals.

Increasing the pedagogical capacity of certified PPKn teachers through training activities and various seminars, workshops and trainings both on a limited scale at school, local scale at district and provincial level, and at national scale.

\section{Obstacles faced by Certified PPKn Teachers in Learning Management:}

The two pedagogical competency levels are in accordance with the research findings as described above, especially in the medium level pedagogical competencies there are various problems or obstacles faced by certified PPKn Vocational School teachers, including:

\section{Teacher's side:}

After being certified there is no guarantee for the teacher concerned to be competent for his pedagogical aspects in the management of learning because of his participation in training to improve his competence. This means that there is very little certified PPKn Vocational School Teachers are given the opportunity to participate in training activities, only to certain individuals because of their level of education such as those of S2 degrees.

\section{School side:}

Schools that are dominated by male students such as SMK Negeri 2 for PPKn teachers in managing learning are very complicated (stubborn, indifferent, don't want to be regulated). While public vocational school 5 which is dominated by female students tends to be more comfortable in learning.

\section{The Student's Side:}

Almost all state vocational schools in Ternate, the characteristics of each student are different, some are difficult to manage, undisciplined (arrive at school on time or disciplined in completing assignments at home). For this condition, the strategies used are: (1) draw closer and embrace students by trying to be good friends; (2) not being discriminating against students in religion, ethnicity, social culture, physicality, and skin color; (3) be polite, wise and good to students so they can see examples and examples.Jejen (Jejen, 2011)says that teachers must know and understand students well, understand the stages of development they have achieved, their abilities, advantages and disadvantages, obstacles encountered and the dominant factors that influence them.

\section{Side time with the weight of the subject matter:}

Not in accordance with the allocation of time with subject matter for reinforcement in everyday life. Sometimes the material is still running when learning time is finished, so the teacher must work extra to complete the material at the next meeting.

\section{The side of the institution that houses the teacher:}

The culture of supervision and supervision has not been programmed in an integrated way between the national education office and the provincial level, so that teachers in the field feel that they are not developing.

\section{The LPTK side that produces teachers:}

The culture of cooperation has not yet been developed for teacher development in stages. There must be some kind of Lab School and Teacher Training Laboratory, if the LPTK does not go to the field then the teacher is invited. 
Various problems faced by teachers as mentioned above, according to Slameto (2011) that the professional development of educators (teachers) must be seen as a pattern of continuous development of educators who do not or lack competent reliable (unqulified) to senior educators at school, including the principal or supervisor. So according to Slameto it must be integrated and sustainable (continuity).

\section{Solution to Overcome the Constraints Faced:}

Refers to what 6 (six) problems or obstacles faced by certified PPKn Vocational School teachers are at the paradigmatic level. This means that things that have been going on for a long time and have not yet been comprehensively resolved, are then linked to what Slameto said, the solutions to overcome these obstacles are:

Follow-up is needed to improve the pedagogical competence of certified PPKn teachers in order to improve the quality of schools in various ways, including through the MGMP. The solution is:

First, collaboration between PPKn teachers between schools through the optimization of MGMP (subject teacher deliberations), educational courses, workshops, supervision and school meetings (Saryati, 2014). In addition it can be done with mutual learning between teachers and conduct lesson studies (Tedjawati, 2011). Doing action research, study groups, case discussions, and lesson studies (Departemen of Education \& Training, 2005) .

Secondly, collaboration between teachers and students as a learning community;

Thirdly, collaboration between schools, the Ministry of Education, teaching, LPMP, LPTK, and AP3KnI to create education and training curricula, workshops and workshops for teacher competency development;

Fourth, cooperation between schools, teachers, students, parents, and the school environment as a unified system that cannot be separated from education. According to Fullan and Langworthy (2014)the role of students also needs to be involved in improving the pedagogical competence of teachers, because with the cooperation of teachers and students, the teacher can understand the mindset of students and develop their learningE.

\section{Conclusion:-}

Based on the results and discussion of the study, it was concluded according to the research problem as follows:

First, the pedagogical competencies of certified PPKn Vocational Schools teachers in Ternate City are only in the medium level pedagogical competencies. After being certified there is no improvement in terms of learning management. Things like making syllabus, lesson plans, mastering teaching materials, class mastery, learning methods and models do not change only are conventional. While advanced-level pedagogical competencies have not yet been found. This level of competence is seen from the mastery of the field of measurable teaching, commitment to the development of methods, models and tools of continuous learning, feasibility research for the continuous development of teaching materials, and participation in various activities, training, seminars, workshops, and good training limited scale at school, district and provincial, and national level.

Second, the obstacles faced by certified PPKn Vocational School teachers in the management of semester learning are very varied, including in terms of teachers, after certification performance increases but there is no change; in terms of schools such as State Vocational School 2 which is dominated by male students who are difficult to regulate, the PPKn teacher must work extra hours to carry out learning in the classroom; in terms of students, almost all state vocational schools in Ternate, the characteristics of each student are different, some are difficult to regulate, undisciplined (coming to school on time or disciplined in completing assignments at home); the time side with the weight of the subject matter, does not match the allocation of time with the subject matter for reinforcement in everyday life. Sometimes the material is still running when the learning is finished; the side of the institution that houses teachers, the culture of supervision and supervision that has not been programmed in an integrated manner between the Ministry of Education and the provincial level; and the LPTK side that produces teachers, has not yet developed a culture of cooperation for gradual teacher development.

Third, the solutions to overcome the obstacles faced are: first, collaboration between PPKn teachers between schools through the optimization of MGMP; second, cooperation between teachers and students as a learning community that learns together; third, collaboration between schools, the ministry of education, teaching, LPMP, LPTK, and AP3KnI to create education and training curricula, workshops and workshops for teacher competency development; 
and fourth, collaboration between schools, teachers, students, parents, and the school environment as a unified system that cannot be separated from education.

\section{References:-}

1. Abosi, O., \& Alhassan, A. R. K. (2017). A Comparative Study of Teachers' Pedagogical Competencies in Supporting Children with Learning Difficulties in Primary School in Ghana and Brunei Darussalam. Journal of the American Academy of Special Education Professionals, 62, pp. 76.

2. Aman (2019). History Teachers' Competence in Implementing Authentic Assessment: A Case Study in a Atate Senior High School in Yogyakarta. International Journal of Learning, Teaching and Educational Research, 18(10), pp. 68-88.

3. Andersson, C. And Palm T. (2017). Characteristics of Improved Formative Assessment Practice. Education Inquiry, 8(2), pp. 104-122.

4. Andryukhina, L. M., Dneprov, S., Sumina, T. G., Zimina, E. Y., Utkina, S. N., \&Mantulenko, V. V. (2016). Vocational Pedagogical Competencies of a Professor in the Socondary Vocational Education System: Approbation of Monitoring Model. International Journal of Environmental and Science Education, 11(14), pp. 7045-7065.

5. Astuty, Eriana. (2015). Implementation Analysis of Lecturer's Pedagogical Competence on Student's Academi Achievement. Journal of Management Research, 7(2) pp. 152-168.

6. Black, P., \& Wiliam, D. (2018). Classroom Assessment and Pedagogy. Assessment in Education: Principles Policy \& Practice, 25(6),pp.551-575.

7. Creswell, John W. (1998). Qualitative Inquiry and Research: Chosing Among Five Traditions. London \& New Delhi: Sage Publication.

8. Cristie, A. J., Jucel, J.,Christine, L., Ester, L. M., Rissa, M., \& Prelyn, S. (2019). Teachers' Perspectives on the Reading and Writing Subject of the Senior High School Curriculum. International Journal of Education and Research,7(6), pp. 309-322.

9. Coe, R., Aloisi, C., Higgins, S and Major, L. E. (2013). What Makes Great Teaching? Review of the Underpinning Research, Center for Evaluation and Monitoring (CEM), Durham University, United Kingdom.

10. Damsar (2012). Introduction to Educational Sociology. Jakarta: Kencana.

11. Departemen of Education \& Training. (2005). Professional Learning in Effective School: The Seven Principles of Highly Effective Professional Learning.Melbourne Leadership and Teacher DevelopmentBranch.Retrived From: http:/www.sofweb.vic.edu.au/blueprint.fs5/def.ault.asp. access: 9 Oktober 2019

12. Forsyth, H., \& Evans, J. (2019). Authentic Assessment for More Inclusive History. Higher Education Research \& Development 38(4), pp. 748-761.

13. Fullan, M. Dan Langworthy, M. (2014). A Rich Seam: How New Pedagogies Find Deep Learning. California: Pearsons.

14. Gumarova, SH., Zubakova, K., Issabaeyva, B., Sayakova, B., \& Sabyrbayeva, N. (2016). The Modern Educational Technology in Proffesional Competence Enchancement of Future Specialists. International Journal of Aplied Engineering Research, 11(5). Pp.3038-3041.

15. He, Ye., Lundgres, K., \& Pynes, P. (2017). Impact of Short-Term Study Abroad Program: Inservice Teacher Development of Intercultural Competence and Pedagogical Beliefst. Teaching and Teacher Education. Volume 66,pp. 147-157.

16. Jejen, Musfah. (2011). Teacher Competency Enhancement: Through Training and Learning Resources Theory and Practice. Jakarta: Kencana.

17. Katarzyna, J., Anna, D., Paulina, K., Anna, M., \& Kinga, S. (2018). Pedagogical Competencies of Teacher at the Beginning of Their Professional Career. Paper Presented at the 1st Intrnational Conference on Temporary Education and Economic Development (CEED 2018).

18. Kuyini, A. B.,Yeboah, K. A., Das, A. K., Al-Hassan, A. M., \& Mangope, B. (2016). Gahanaian Teacher Competencies Perceived as Important for Inclusive Education. International Journal of Inclusive Education. 20(10), pp. 1009-1023.

19. Lauermann, F., \& Koig, J. (2016). Teacher' Professional Competence and Wellbeing: Understanding the Link Between General Pedagogical Knowledge, Self-Efficacy and Burnout. Leraning and Instruction, 45, pp. 9-19.

20. Law Number 14 of 2005, Concerning Teachers and Lecturers.

21. Ministry of Education. (2004). Teacher Competency Standards. Jakarta: Directorate of Education Personnel.

22. Mirzagitova, A. L., \& Akhmetov, L. G. (2015). Self-Development of Pedagogical Competence of Future Teacher. International Education Studies, 8(3), pp. 114-121

23. Mulyasa, E. (2013). Teacher Competency Standards and Certification. Bandung: Teen Rosdakarya. 
24. Ningtiyas, F. A \& Jailani. (2018). Does Teacher's Training Affect the Pedagogical Competence of Mathematics Teacher?. Journal of Physic: Conference Series, Conf.Series 1097 (2018) 012106.doi:1088/1742$6596 / 1097 / 1 / 012106$.

25. Raju, J. (2017). To Teach or not to Teach? The Question of the Academic Librarian's Pedagogical Competencies in the Digitas Age. South African Journal of Higher Education, 31(2), pp. 251-269.

26. Riyad, M., Munakib., Abdullah, T \& Rernowati, R. (2020). Measuring the Profesionality of School Teachers' Performance: The Context, Process, and Product (CIPP) Model. International Jurnal of Innovation, Creativity and Change, 12(3), 386-399.

27. Saryati. (2014). Efforts to Improve Pedagogical Competence of Elementary School Teachers. Journal of Educational Administration, 2 (1). Ejournal.

28. Tedjawati. J. M. (2011). Teacher Competency Enhancement Through Lesson Study: Cases in Bantul District. Journal of Education and Culture. 17(4), pp.483

29. Vu, T. T., \& Dall'Alba, G. (2014). Authentic Assessment for Student Learning: An Ontological Conceptualization. Educational Philosophy and Theory, 46(7), 778-791.

30. Siswoyo, Dwi et al. (2016). Education. Yogyakarta: Yogyakarta State University Press.

31. Slameto (2011). Learning and Factors That Influence It. Jakarta: Rineka Cipta.

32. Sukmadinata, Nana Saodih. (2009). Curriculum Development: Theory and Practice. Bandung: Teen Rosdakarya.

33. Vulliamy, G., \& Webb, R. (2018). Teacher Research and Special Education Needs. Routledge. 